\title{
INCIDENCE AND PREVALENCE OF TOXOPLASMOSIS AMONG SHEEP AND GOATS IN SOUTHERN AND WESTERN BOHEMIA
}

\author{
K. HEJLÍ́EK ${ }^{1}$ and I. LITERÁK ${ }^{2}$ \\ 1 „Vedia“, Private veterinary laboratory, 38601 Strakonice \\ 2 Department of Infectious Diseases and Epizootiology, University of Veterinary \\ and Pharmaceutical Sciences, 61242 Brno
}

Received October 27, 1993

\begin{abstract}
Hejlíček K., Literák I: Incidence and Prevalence of Toxoplasmosis Among Sheep and Goats in Southern and Western Bohemia. Acta vet. Bmo, 63, 1994: 151-159.

Incidence and prevalence of toxoplasmosis in several flocks of sheep and goats in southern and western parts of Bohemia were studied, together with some factors influencing the infection.

From 1982 to 1989 , a total of 899 slaughter sheep was examined in the Strakonice abbatior, 780 of them from small privately-owned flocks and 119 from larger flocks of agricultural cooperatives. Antibodies to T.gondii were detected by Sabin-Feldmann dye test (DT) in $54.6 \%$ (56.5\% and $42.1 \%$ ), by complement fixation reaction (CFT) in $40.1 \%(43.8 \%$ and $28.1 \%)$ and by microprecipitation in agar gel (MPA) in 3.6\% (3.8\% and 1.7\%). T.gondii was detected in 4.8\% (5.4\% and 1.7\%). Both seroprevalence and T.gondii incidence were higher among sheep from small, privately-owned flocks than among sheep from cooperative farms. Levels of antibodies detected by DT and CFT remained very much the same throughout the study period. Prevalence of DT and CFT antibodies was significantly $(P<0.05$, $P<0.005$ resp.) higher in spring and autumn than in summer and winter.

In 1986-1990, 341 blood serum samples from two small private flocks in the Strakonice district were examined. The DT was positive in $67.1 \%$, CFT in $22.5 \%$ and MPA in $0.7 \%$. The difference between the two flocks in incidence of antibodies detected by DT was significant. The incidence of antibodies remained on practically the same level over the entire period. Higher antibody levels were found in sheep examined in spring and summer, but they were not statistically different from levels ascertained in autumn and winter.

Repeated biological semen examination of eleven rams, seven of which were positively DT-tested for antibodies, failed to prove the presence of $T$.gondii.

In 1981-1990, a total of 54 blood serum samples from five small goat flocks were examined. Antibodies were detected by DT and CFT in $61.1 \%$ and $21.0 \%$ respectively. In all the five flocks, antibodies were detected by DT. Their levels peaked in summer and autumn.

A serological examination of 125 sheep from a military training area in southern Bohemia revealed antibodies in $45.6 \%$ and $12.8 \%$ by DT and CFT, respectively. DT and CFT performed on 196 sheep from a military training area in western Bohemia revealed seropositivity in $73.9 \%$ and $21.9 \%$ respectively.

The results showed that the prevalence of toxoplasmosis among sheep and goats in areas investigated is considerable. Its prevalence among sheep in small, privately-owned flocks is higher than in larger flocks of agricultural enterprises. Antibodies to toxoplasmosis tend to stay in sheep for a long time and they are found much more frequently than their causative agent can be detected in tissues. In none of the sheep or goat flocks examined, clinical expressions of toxoplasmosis were observed.
\end{abstract}

Toxoplasma gondii, sheep, goats, Sabin-Feldmann dye test (DT), complement fixation test (CFT), microprecipitation in agar gel (MPA), monitoring, husbandry.

Toxoplasmosis among sheep and goats has been reported from all over the world (B le wett and W at son, 1984; Dub ey and B e at ti e, 1988). In our circumstances, the main source of $T$. gondii among sheep and goats is the domestic cat. Its faeces containing toxoplasmosis oocysts contaminate either the facilities where animals are kept, their feed (Pl an t et al. 1974, McSporran etal. 1985, Nurse and Len gh au s, 1986) orbedding (Faul etal. 1986). An intrauterine transmission from one sheep to another is also the frequent type of transfer. The result is either an abortion or the birth of congenitally infected young (B artko 1979, A rna udov et al. 1976, Ni colas et al. 1978, B le wett et al. 1982, Ca la mel 1982 , Du be y and W e l c o me, 1988, inter alia). Similarly, an intrauterine transfer of $T$.gondii among goats has been described (Calamel and Giauffret, 1975, Munday and Mason, 1979, Plant et al. 1980, Dubey et al. 1980, 1985, Dubey 1981, 1982, and others). S pence et al. (1978) and Te a le et al. (1982) reported excretion of T.gondii in the semen of experimentally infected rams. B le w ett et al. (1982), however, failed to demonstrate a transmission of T.gondii to healthy sheep tupped by rams with chronic toxoplasmosis. Dubey and Sharma (1980) demonstrated long-term excretion of $T$. gondii in semen after experimental infection with toxoplasma oocysts. Agent transmission from experimentally infected sheep to healthy ones during their contact was not demonstrated (B icknell 1972, Mich a el et al. 1972), although B e verle y etal. (1975) pointed out that oocysts of $T$. gondii may pass through the digestive tract without opening up, which 
would create an opportunity for the spreading of oocysts in the faeces of infected sheep. Similarly, $\mathrm{O}$ w e $\mathrm{n}$ and $\mathrm{Ch}$ e $\mathrm{u} \mathrm{m}$ (1975) stressed the importance of amniotic fluid and amnions in toxoplasma abortions as a possible source of $T$. gondii. Schurian (1969) and R u p p a n e r et al. (1978) failed to demonstrate toxoplasmosis agent excretion in milk of latently infected sheep and goats respectively. R i e m a n n et al. (1975), on the other hand, demonstrated $T$.gondii in goat milk. In goats experimentally infected with a large number of oocysts, Du b e y (1980) reported excretion of $T$.gondii in milk only exceptionally and he believes that the risk of toxoplasmosis incidence in milk of naturally infected goats is minimal.

In monitoring toxoplasmosis incidence and prevalence among sheep and goats, attention was also paid to other factors influencing its epizootiology. Cal a mel (1982) and W alde land (1976) concluded that toxoplasmosis affected flocks of sheep and goats with no geographical influence. Later, however, W al d e l a n d (1977) reported that toxoplasmosis was more frequent among animals from lowland pastures, and more frequently in winter than in summer, than among animals on mountain pastures in uninhabited countryside. A r n a ud ov et al. (1976), on the other hand, found higher seropositivity among sheep in montainous areas than in lowlands. D u be y and Welc om (1988) found a higher percentage of serologic reactions to toxoplasmosis in older sheep. Higher seropositivity was also found among older goats (M ach ado and Li m a 1987, Du be y and Ada m s 1990). Husbandryrelated differences in toxoplasmosis incidence have also been reported. M a ch a do and Li m a (1987) found the highest seropositivity among goats raised for meat and milk, lower among dairy goats raised on private farms, and the lowest among goats raised intensively for meat. Ch i a $\mathrm{i}$ et al. (1987) found a significantly higher percentage of antibodies among goats raised in towns and neighbouring areas than in the country. Mach a do (1985) demonstrated higher seropositivity among goats on private farms than on dairy farms or extensive breeding farms.

The aim of the present study was to investigate the incidence and prevalence of toxoplasmosis among sheep and goats in southern and western Bohemia as a part of a comprehensive study of animal toxoplasmosis, and to identify influences that affect the occurrence and spreading of the infection.

\section{Materials and Methods}

A. Between 1982 and 1990, the following examinations were made in a south Bohemian district of Strakonice:

1. Between 1982 and 1989, samples of blood, brain and diaphragm muscle were collected in one month intervals from slaughtered sheep. The samples were collected from 10 to 15 sheep as they were slaughtered on that day. Most of the sheep were from small, privately-owned flocks, the rest from larger flocks raised by local agricultural enterprises.

2. Between 1986 and 1990 , blood samples were taken regularly in three-month intervals from two small flocks of sheep.

3. In 1984, semen of 11 rams from a large flock of a local agricultural enterprise was taken several times in 17 dayintervals.

4. In 1981-84, blood samples of goats from two small flocks were taken occasionally, and in 1986-1990, blood samples of goats from three small flocks were taken regularly, as in the case of sheep.

B. In 1987 and 1988, blood samples of sheep raised in large flocks in two military training areas in southern and western Bohemia were taken.

Serological examinations to demonstrate the presence of antibodies against T.gondii, DT (titre 24 ), CFT (titre $\geq 10$ ), MPA and an isolation experiment of the causative agent from tissues, were made in the same way as in cattle (Hejlícek and Literák, 1992).

The ram semen was diluted with sterile physiological saline and antibiotics in 1:2 ratio, and applied intraperitoneally in $1 \mathrm{~cm}^{3}$ doses to white mice. Further examinations were the same as in the tissue assay.

Statistical analysis was done using the $\chi^{2}$ test.

\section{Results}

\section{A. Strakonice district examinations}

1. A total of 899 slaughter sheep were examined, 780 of which were from small, privately-owned flocks and 119 from larger flocks of agricultural enterprises (Tab. 1). DT was used to examine

Table 1

Incidence of antibodies to toxoplasmosis and demonstration of $T$. gondii in tissues of slaughter sheep in Strakonice region from 1982 to 1989

(DT = Sabin-Feldmann dye test, CFT = complement fixation test, MPA = microprecipitation in agar gel)

\begin{tabular}{|l|c|c|c|c|}
\hline Origin of animals & \multicolumn{4}{|c|}{ Percent of positive sheep } \\
\hline \multirow{2}{*}{ Small, privately-owned flocks $(\mathrm{n}=780)$} & SD (titre $\geq 4)$ & CFT (titre $\geq 10)$ & MPA & T. gondii isolation \\
\cline { 2 - 5 } Large flocks from ag enterprises $(n=119)$ & $56.5^{\mathrm{a}}(\mathrm{n}=767)$ & $43.0^{\mathrm{b}}(\mathrm{n}=388)$ & $3.8^{\mathrm{c}}(\mathrm{n}=627)$ & $5.4^{\mathrm{d}}(\mathrm{n}=670)$ \\
& $42.1^{\mathrm{a}}(\mathrm{n}=119)$ & $28.1^{\mathrm{b}}(\mathrm{n}=96)$ & $1.7^{\mathrm{c}}(\mathrm{n}=59)$ & $1.7^{\mathrm{d}}(\mathrm{n}=116)$ \\
\hline Total $(\mathrm{n}=899)$ & $54.6(\mathrm{n}=886)$ & $40.1(\mathrm{n}=484)$ & $3.6(\mathrm{n}=686)$ & $4.8(\mathrm{n}=786)$ \\
\hline
\end{tabular}

a) significant difference $\left(\chi^{2}=8.2, \mathrm{df}=1, \mathrm{P}<0.005\right)$

b) significant difference $\left(\chi^{2}=6.6, \mathrm{df}=1, P<0.05\right)$

c, d) non-singificant ( $\chi^{2}$ test, Fisher test, $P>0,05$ ) 
886 sheep (767 and 119), of which $54.6 \%$ (56.5\% and 42.1) tested positive; CFT was used in 484 sheep (388 and 96), of which $40.1 \%$ (43.0 and $28.1 \%$ ) tested positive. MPA was used in 686 slaughter sheep (627 and 59), of which $3.6 \%$ (3.8\% and $1.7 \%$ ) tested positive. The presence of T.gondii was demonstrated in $4.8 \%$ (5.4\% and $1.7 \%$ ) of the 786 (670 and 116) sheep examined.

Incidence of antibodies detected by DT throughout the entire study period (Fig. 1), as well as the geometric mean of titres $(\overline{\mathrm{x}} \mathrm{g})$, remained relatively unchanged. The demonstration of T.gondii from tissues peaked in 1987. The incidence of CFT-tested antibodies reached its highest level in 1988, although $\bar{x} g$ remained the same.

Fig. 1

Prevalence of antibodies to $T$. gondii and incidence of $T$. gondii among sheep slaughtered in the Strakonice abattoir in individual seasons of the year (1982-1989) (CFT complement fixation test)

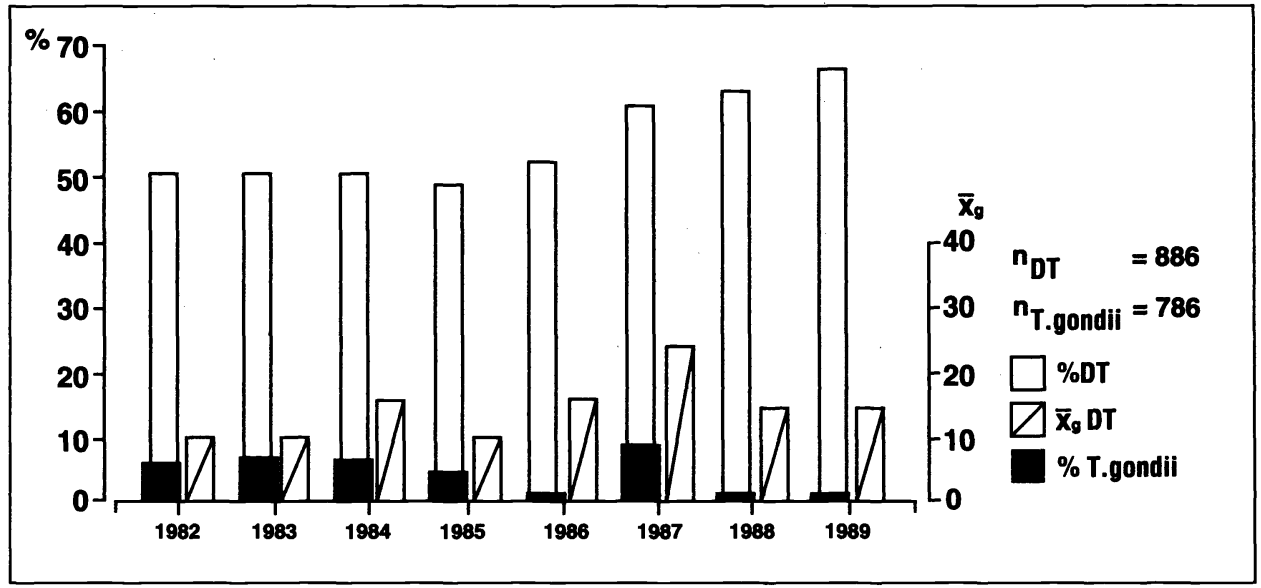

Prevalence of DT- and CFT-tested antibodies was significantly different in individual seasons of the year $\left(\chi 2_{\mathrm{DT}}=8.5 \mathrm{df}=3 \mathrm{P}<0.05 ; \chi 2_{\mathrm{CFT}}=11.2 \mathrm{df}=3 \mathrm{P}<0.005\right)$ (Fig. 2a, 2b). An increase was observed in spring and autumn, and a decrease in winter and summer. No significant changes in tissue assays of T.gondii in individual seasons were found.

2. A total of 341 blood samples were taken from sheep in two small, privately-owned flocks (Tab. 2), of which 340 samples were tested by DT (67.1\% positive), 329 were tested by CFT (22.5\% positive) and 298 serum samples were tested by MPA ( $0.7 \%$ positive). The two flocks differed significantly in the levels of antibodies detected by DT, while no significant differences in the levels of antibodies detected by CFT or MPA were found.

Table 2

Prevalence of antibodies to toxoplasmosis among sheep in two small privately-owned flocks in Strakonice district

\begin{tabular}{|l|c|c|c|c|}
\hline \multirow{2}{*}{ Farm } & \multirow{3}{*}{ Monitoring Period } & \multicolumn{3}{|c|}{ Percent of positive sheep } \\
\cline { 3 - 5 } & & DT & CFR & MPA \\
\hline 1 (S. R.) & $1986-1990$ & $78.1^{\mathrm{a}}(\mathrm{n}=201)$ & $25.2^{\mathrm{b}}(\mathrm{n}=198)$ & $1.1(\mathrm{n}=175)$ \\
2 (K. N.) & $1986-1990$ & $53.2^{\mathrm{a}}(\mathrm{n}=139)$ & $18.3^{\mathrm{b}}(\mathrm{n}=131)$ & $0(\mathrm{n}=123)$ \\
Total & $1986-1990$ & $67.9^{\mathrm{aa}}(\mathrm{n}=340)$ & $22.5^{\mathrm{bb}}(\mathrm{n}=329)$ & $0.7(\mathrm{n}=298)$ \\
\hline
\end{tabular}

bb) non-significant (sheep:goat) $\left(\chi^{2}\right.$ test, $\left.P<0.05\right)$ 
Fig. 2

Prevalence of antibodies to $T$. gondii and incidence of $T$. gondii among sheep slaughtered in the Strakonice abattoir in individual years (DT = Sabin-Feldmann dye test g = geometric mean of titre)

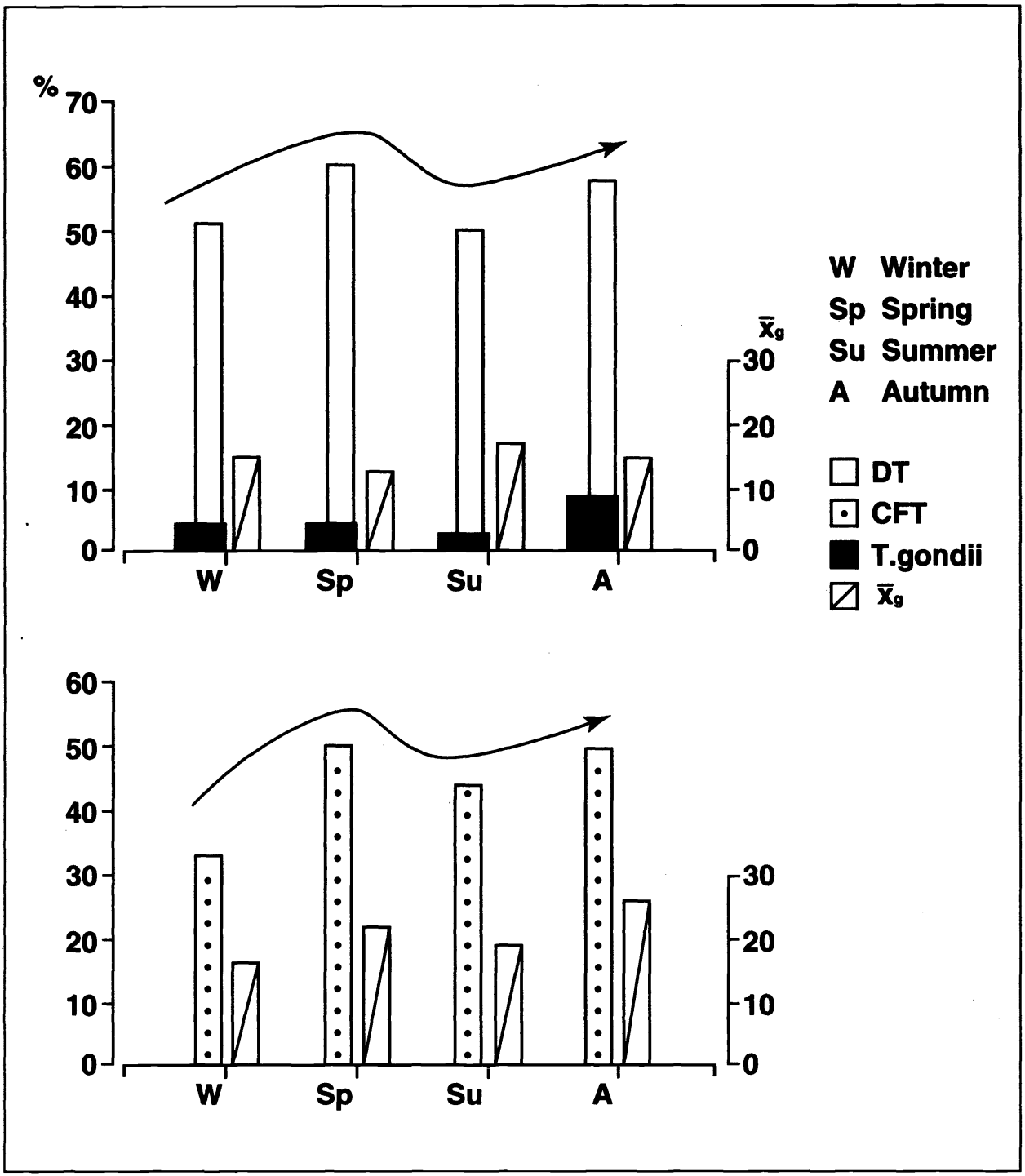

The prevalence rate of antibodies changed little in individual years (between 1986 and 1990), with the highest percentage being recorded in 1988. DT and CFT detected antibodies more frequently in spring and summer, but the difference from other seasons (autumn and winter) was not significant.

3. Blood serum antibodies were found in seven of the eleven DT-tested rams. The titres were from 8 to 64 . Biological experiments with repeatedly taken semen, however, failed to demonstrate the presence of $T$.gondii. 
4. A total of 54 blood serum samples from goats in five small, privately-owned flocks was examined (Tab. 3) DT and CFT detected antibodies in $61.1 \%$ and $21.0 \%$ respectively. Antibodies were found in all five flocks where DT were used. The highest percentages of positive results in DT and CFT were recorded in summer and, somewhat lower, in autumn.

Table 3

Prevalence of antibodies to toxoplasmosis among goats in five small, privately-owned flocks in Strakonice district

\begin{tabular}{|c|c|c|c|c|}
\hline \multirow{2}{*}{ Farm } & \multirow{2}{*}{$\begin{array}{l}\text { Monitoring } \\
\text { period }\end{array}$} & \multicolumn{3}{|c|}{ No. of positive (No. of examined goats) } \\
\hline & & DT & CFR & MPA \\
\hline $\begin{array}{l}1 \text { (M. V.) } \\
2 \text { (R. V.) } \\
3 \text { (L. T.) } \\
4 \text { (A. K.) } \\
5 \text { (K. N.) } \\
\text { Total }\end{array}$ & $\begin{array}{l}1981-1984 \\
1981-1984 \\
1986-1990 \\
1986-1990 \\
1986-1990 \\
1981-1990\end{array}$ & $\begin{array}{l}2 / 10 \\
4 / 5 \\
16 / 22 \\
2 / 2 \\
9 / 15 \\
33 / 54^{\text {aa }}(61.1 \%)\end{array}$ & $\begin{array}{l}\text { nt } \\
\text { nt } \\
6 / 22 \\
0 / 2 \\
2 / 14 \\
8 / 38^{\text {bb }}(21.0 \%)\end{array}$ & $\begin{array}{l}\text { nt } \\
\text { nt } \\
0 / 20 \\
0 / 1 \\
0 / 13 \\
0 / 34(0 \%)\end{array}$ \\
\hline
\end{tabular}

nt $=$ not serologically tested

aa) no significant (sheep:goat) $\left(\chi^{2}\right.$ test, $\left.P>0.05\right)$

bb) no significant (sheep:goat) $\left(\chi^{2}\right.$ test, $\left.P>0.05\right)$

\section{B. Examinations in two military training areas}

In a military training area in south Bohemia, the authors examined 125 sheep, which tested positive by DT and CFT in $45.6 \%$ and $12.8 \%$ respectively. Of the 196 sheep examined in a west Bohemian training area, $73.9 \%$ and $21.9 \%$ tested positive by DT and CFT respectively.

\section{Discussion}

In 1982-89, a total of 899 sheep slaughtered in the Strakonice abattoir were tested for toxoplasmosis. DT tested positive in 54.6\%, CFT in $40.1 \%$, MPA in $3.6 \%$ and an isolation experiment in $4.8 \%$. These findings are in a general agreement with results obtained in toxoplasmosis examinations in sheep in Czechoslovakia (DT 80\%, CFT 26\%, isolation experiment 13\%), as summarized for a period of 1948-1970 by Kouba et al. (1974). They are, however, considerably higher than those reported for DT by Surveillance of Antropozoonosis in the Czech Republic for 1979-1990 (22.7\%) and those reported for CFT from the Slovak Republic for the 1988 - 1991 period (9.7\%) by Kováčová (1993). Higher findings in our group of slaughter sheep could be explained by the fact that this region has a markedly higher incidence of antibodies to toxoplasmosis also in beef cattle $(4.1 \%$, Hejlíček and Literák, 1992), compared to the 1979-1990 average in the Czech Republic (1.4\%) reported by Surveillance of Antropozoonosis. Besides, our group consisted mostly of sheep from small, privately-owned flocks ( 780 out of 899 ), where the risk of toxoplasma oocyst infection is higher than in larger flocks that are raised in sheep-pens and on pastures. This is also demonstrated by a comparison of results of examinations in small, privately-owned sheep flocks and large flocks from agricultural cooperatives, where positive results of DT and CFT in the former were significantly higher. Levels of positive results of DT and $\bar{x} g$ remained practically the same over the years, which is a proof of a permanent occurrence of toxoplasma oocysts in the environment excreted by the domestic cat, and of a long prevalence of antibodies to toxoplasma in infected sheep, which was already pointed out by B le w ett (1983). This might also explain a difference between the high DT-detected seropositivity (54.6\%) and a relatively small number of positive demonstrations of agents in tissues (4.8\%). Similar findings in slaughter sheep were also reported by Punke (1973).

A significantly higher prevalence of antibodies detected by DT and CFT was found among sheep slaughtered in spring and autumn. In spring, a newly born feline population, which 
is very sensitive, is infected and excretes oocysts in faeces. Higher incidence of antibodies in autumn may be related to the fact that mostly old and culled sheep, which are more frequently infected with $T$.gondii, are slaughtered at that time. This assumption is supported by a more frequent identification of $T$.gondii in tissues of sheep examined in autumn. A higher percentage of serologic responses in older sheep was also reported by Dubey and Welcome (1988).

The five-year serologic study of sheep in two privately-owned flocks revealed significant differences in DT-positivity. This is apparently related to the local epizootiological situation in source availability. Average seropositivity in sheep from the two flocks was not markedly different from that among slaughter sheep from small privately-owned flocks. Just as in slaughter sheep, no significant differences in prevalence of antibodies to toxoplasma or geometric mean of titres in individual years were observed. Incidence of antibodies in individual years did not vary significantly, with the highest percentage being reached in spring and summer. This was apparently due to the contamination of the environment with oocysts from a newly born population of cats. Lower autumn prevalence of antibodies in comparison with slaughter sheep can be explained by the fact that, rather than monitoring only older or culled sheep, all sheep in the flock were monitored. This pattern of prevalence of antibodies in small flocks, with its peaks in spring and summer, may be considered quite representative, and it clearly identifies the role of cats, particularly younger ones, in influencing the epizootiological situation in sheep toxoplasmosis.

A repeated biological assay of the ejaculum of 11 rams, seven of which tested positive by DT, failed to prove the presence of T.gondii. Therefore, we were not able to confirm the report of T.gondii excretion in ram semen, as published by S p e n c e et al. (1978) and Te a le et al. (1982). These authors, however, examined experimentally infected rams. Results of our study seem to be more in agreement with observations of B l e w e $t$ t et al. (1982), who failed to demonstrate a transfer of $T$.gondii to healthy sheep tupped by rams with chronic toxoplasmosis. No increase in the number of abortions was observed in the flock where 11 rams were examined.

A total of 54 blood samples was taken in five small goat flocks. With regard to the incidence of antibodies (DT 61.1\%, CFT 21.0\%), no significant difference was found from the number of positive samples from small, privately-owned sheep flocks. Although only a small number of samples was examined, antibodies were found most frequently in summer and autumn. Compared to sheep in small flocks where the prevalence of antibodies reached the highest level in spring and summer, this represents a certain shift. It can be explained by the fact that goats in that region are brought to pastures later in spring than sheep, which delays their infection with toxoplasma oocysts.

To provide more background information on the incidence and prevalence of toxoplasmosis among sheep in the Strakonice district, we made a single examination of sheep from two different locations in southern and western Bohemia. They were both military training areas, sparsely populated and with little production activity. High seropositivity in sheep raised in those areas can be explained by the presence of cats in an immediate vicinity of sheep pens, a high sensitivity of sheep to infection and a long survival of antibodies in blood. The areas are large and sparsely inhabited, and a contamination of pastures with oocysts of $T$.gondii is therefore unlikely.

No increase in the number of abortions was observed in either of the flocks.

\section{Výskyt a rozšíření toxoplazmózy u ovcí a koz v jižních a západních Cechách}

Byl sledován výskyt a rozšriření toxoplazmózy $\mathrm{v}$ chovech ovcí a koz na území jižních a západních Čech, spolu s některými faktory ovlivňujícími nákazovou situaci. 
V roce 1982-1989 bylo vyšetřeno na jatkách ve Strakonicích 899 jatečných ovcí, $\mathrm{z}$ toho $780 \mathrm{z}$ malých soukromých chovủ a $119 \mathrm{z}$ větších chovủ zemědělských závodủ. Protilátky proti $T$. gondii byly prokázány SFR (Sabin-Feldmanova reakce) v 54,6\% (56,5\% a 42,1\%), KFR (komplementfixační reakce) ve 40,1 \% (43,8 \% a 28,1 \%), MPA (mikroprecipilace v agarovém gelu) ve $3,6 \%(3,8 \%$ a $1,7 \%)$. Prítomnost $T$. gondii byla zjištěna ve $4,8 \%$ $(5,4 \%$ a $1,7 \%)$. Séroprevalence i výskyt $T$. gondii byly vyšsí u ovcí v malých, soukromých chovech než ve větších chovech zemědělských závodủ. V jednotlivých létech zủstávaly nálezy SFR a KFR protilátek celkem rovnoměrné. Výskyt SFR a KFR protilátek byl na jaře a na podzim signifikantně vyš̌í než v létě a v zimè.

V roce 1986-1990 bylo vyšetřeno ve dvou malých, soukromých chovech na okrese Strakonice 341 vzorkủ krevního séra ovcí. SFR byla poztivní v 67,1\%, KFR ve 22,5\%, MPA v $0,7 \%$. Mezi oběma chovy byl signifikantní rozdíl ve výskytu SFR protilátek. Výskyt protilátek $\mathrm{v}$ prủběhu jednotlivých let byl vcelku vyrovnaný. Vyšší nález protilátek byl u ovcí vyšetřovaných na jaře a $v$ létě, avšak signifikantně se od nálezu na podzim a v zimě nelišil.

Płi opakovaném vyšetření semene 11 beranủ, $z$ nichž 7 bylo se SFR protilátkami, se biologickým pokusem nepodařilo prokázat $T$. gondii.

V roce 1981-1990 bylo vyšetřeno v 5 malých chovech 54 vzorkủ krevního séra koz. Výskyt SFR a KFR protilátek čnil $61,1 \%$ a $21,0 \%$. Ve vsech 5 malých chovech byly zjištěny u koz SFR protilátky. Nejvyšsí výskyt protilátek byl v létě a pak na podzim.

Sérologickým vyšetłením 125 ovcí ve vojenském výcvikovém prostoru na území jižních Cech byly zjištěny SFR protilátky ve $45,6 \%$, KFR ve $12,8 \%$. Ve vojenském výcvikovém prostoru v západních Čechách bylo vyšetřeno 196 ovcí, z toho SFR pozitivita cinila 73,9\%, KFR 21,9\%.

Výsledky prokázaly, že toxoplazmóza ovcí a koz je ve sledovaných lokalitách značnè rozšífena. U ovcí je vyšší výskyt v malých, soukromých chovech než ve větších chovech zemědělských závodủ. Protilátky proti toxoplazmóze mají tendenci u ovcí dlouho přetrvávat a nacházejí se výrazně častěji, než se daři prokazovat původce ve tkáních. V žádném ze sledovaných chovů ovcí a koz nebyly pozorovány klinické projevy toxoplazmózy.

\section{Наличиө и распространөниө токсоплазмоза овөц и коз в южной и западной Чехии}

Проводили исследования наличия и распространения токсоплазмоза овец и коз на территории южной и западной Чехии совместно с некоторыми факторами, оказывающими влияние на заражение.

В 1982-1989 гг. на скотобойне в Страконицах исследовали 899 убойных овец, из этого 780 овец из небольших частных овцеводческих хозяйств и 119 из крупных овцеводческих заводов. Антитела против T. gondii были выявлены SFR 54,6 \% (56,5 \% и 42,1 \%), KFR 40,1 $\%$ (43,8 \% и 28,1\%), МРA 3,6 \% (3,8 \% и 1,7\%). Наличие T. gondii было установлено в 4,8 $\%$ (5,4 \% и 1,7\%). Серопревалирование и лаличие $T$. gondii были больше у особей небольших, частных овцеводческих хозяйств чем у овец крупных овцеводческих ферм. В отдельные годы данные SFR и KFR антител оставались в общем равномерными. По сравнению с летним и зимним периодом, наличие SFR и KFR антител было весьной существенно больше.

В 1986-1990 гг. исследовали на двух частных овцеводческих фермах района Страконице 341 образец сыворотки крово овец. Данные SFR были позитивными в 67,1 \%, KFR - 22,5 \%, MPA - 0,7\%. Между обоими овцеводствами наблюдалась существенная разница в наличии SFR антител. Наличие антител в отдельные годы было в общем уравновешенным. Болшее наличие антител овец, исследуемых весной и летом однако от антител, полученных осенью и зимой не отличалось. 
При повторном исследовании семени 11 баранов 7 из них c SFR антителами биологическим экспериментом не удалось установить T. gondii .

В 1981-1990 гг. исследовали на 5 небольших фермах 54 образца кровяной сыворотки коз. Наличие SFR и KFR антител достигало 61,1\% и 21,0\%. На всех пяти фермах были у коз выявлены SFR антитела. Самое большое наличие антител относится к летнему и осеннему нериоду.

Серологическим исследованием 125 овец в военном учебном лагере на мерритории южной Чехии быливыявлены SFR антитела в 45,6\%, KFR-12,8\%. Ввоенном учебном лагере в западной Чехии исследовали 196 овец, из этого SFR позитивных достигали 73,9\%, KFR-21,9\%.

Результаты выявилы, что токсоплазмоз овец и коз на исследуемых местах нашел значительное распространение. У овец наблюдается больше на частных овцеводческих фермах чем на крупных овцеводствах. Антитела против токсоплазмоза отличаются большей устойчивостью и встречаются гораздо чаще, чем удается выявить возбудителья в тканях. Ни в одном из ислледуемых овцеводческих хозяйств и стадах коз не наблюдали клинические проявления токсоплазмоза.

\section{References}

ARNAUDOV, D. - KOZOJED, V. - JIRA, J. - ŠTTOURAČ, L.: Imunoepizootologická studie ovčí toxoplazmózy. Veter. Med. (Praha), 21, 1976: 375-384

BARTKO, J.: Toxoplazmóza oviec v nížinnej oblasti západného Slovenska. Veter. Med. (Praha), 24, 1979: 285-294

BEVERLEY, J. K. A. - HUTCHISON, W. M.-ALLSUP, T. N. - SPENCE, J. B. - WATSON, W. A.: Studies on the spread of Toxoplasma gondii to sheep. Brit. Veter. J., 131, 1975: 130-136

BICKNELL, S. R.: An unsuccessful attempt to transmit toxoplasmosis to mice from the faeces of artificially infected sheep. Brit. Veter. J., 128, 1972: xi

BLEWETT, D. A. - TEALE, A. J. - MILLER, J. K. - SCOTT, G. R. - BUXTON, D.: Toxoplasmosis in rams: possible significance of veneral transmission. Veter. Rec., 111, 1982: 73-75

BLEWETT, D. A. - MILLER, J. K. - BUXTON, D.: Response of immune and susceptible ewes to infection with Toxoplasma gondii. Veter. Rec., 111, 1982: 175-177

BLEWETT, D. A.: The epidemiology of ovine toxoplasmosis. I. The interpretation of data for the prevalence of antibody in sheep and other host species. Brit. Veter. J., 139, 1983: 537-545

BLEWETT, D. A. - WATSON, W. A.: The epidemiology of ovine toxoplasmosis. III. Observations on outbreaks of clinical toxoplasmosis in relation to possible mechanisms of transmission. Brit. Veter. J., 140, 1984: 54-63

CALAMEL, M. - GIAUFFRET, A.: Une enzootie de toxoplasmose caprine abortive. Bull. Acad. vétér. France, 48, 1975: 41-51

CALAMEL, M.: Épidémiologie de la toxoplasmose abortive chez les petits ruminants. Note 1, note 2. Rev. Méd. vétér., 133, 1982: 115-119, 121-124

CHIARI, C. de A. - LIMA, J. D. - LIMA, W. dos S. - AUTUNES, C. M. de F.: Soro-epidemiologia de toxoplasmose caprina em Minas Gerais, Brasil. Arq. bras. Med. Veter. e Zootechn., 39, 1987: 587-609

DUBEY, J.P.: Persistence of encysted Toxoplasma gondii in caprine livers and public health significance of toxoplasmosis in goats. J. Amer. veter. med. Assoc., 177, 1980: 1203-1207

DUBEY, J. P. - SHARMA, S. P. - LOPES, C. W. G. - WILLIAMS, J. F. - WILLIAMS, C. S. F. - WEISBRODE, S. E.: Caprine toxoplasmosis: abortion, clinical signs, and distribution of Toxoplasma in tissues of goats fed Toxoplasma gondii oocysts. Amer. J. veter. Res., 41, 1980: 1072-1076

DUBEY, J. P. - SHARMA, S. P.: Prolonged excretion of Toxoplasma gondii in semen of goats. Amer. J. veter. Res., 41, 1980: 794-795

DUBEY, J. P.: Toxoplasma-induced abortion in dairy goats. J. Amer. veter. med. Assoc., 178, 1981: 671-674

DUBEY, J. P.: Repeat transplacental transfer of Toxoplasma gondii in dairy goats. J. Amer. veter. med. Assoc., 180, 1982: 1220-1221

DUBEY, J. P. - DESMONTS, G. - ANTUNES, F. - McDONALD, C.: Serologic diagnosis of toxoplasmosis in experimentally infected pregnant goats and transplacentally infected kids. Amer. J. veter. Res., 46, 1985: $1137-1140$

DUBEY, J. P. - BEATTIE, C. P.: Toxoplasmosis of Animals and Man. CRC Press, Boca Raton, Florida, 1988

DUBEY, J. P. - WELCOME, F. L.: Toxoplasma gondii induced abortion in sheep. J. Amer. veter. med. Assoc., 193, 1988: 697-700

DUBEY, J. P. - ADAMS, D. S.: Prevalence of Toxoplasma gondii antibodies in dairy goats from 1982 to 1984. J. Amer. veter. med. Assoc., 196, 1990: 295-296

FAULL, W. B. - CLARKSON, M. J. - WINTER, A. C.: Toxoplasmosis in a flock of sheep: some investigations into its source and control. Veter. Rec., 119, 1986: 491-493 
HEJLIČEK, K. - LITERAK, I.: Occurence of toxoplasmosis and its prevalence in cattle in the south Bohemian region. Acta Vet. Brno, 61, 1992: 195-206

KOUBA, K. - JIRA, J. - HÜBNER, J.: Toxoplazmóza. Avicenum, Praha, 1974.

KOVÁČOVÁ, D.: Sérologická prevalencia Toxoplasma gondii u oviec. Veterinářství, 43, 1993: 51-54

McSPORRAN, K. D. - McCAUGHAN, C. - CURRAL, J. H. S. - DEMSTEEGT, A.: Toxoplasmosis in goats. N. Z. veter. J., 33, 1985: 39-40

MACHADO, T. M. M.: Frequiencia de anticorpos anti-Toxoplasma gondii em caprinos criados sob diferentes formas de exploração no Estado de Minas Gerais. Arq. bras. Med. Veter. e Zootech., 37, 1985: 73-76

MACHADO, T. M. M. - LIMA. J. D.: Freqüência de anticorpos anti-Toxoplasma gondii em caprinos criados sob diferentes formas de exploração no Estado de Minas Gerais. Arq. bras. Med. Veter. e Zootechn., 39, 1987: 255-264

MICHAEL, S. A. - EL-REFAII, A. H. - SELIM, M. K.: Vorläufige Untersuchungen über die experimentelle Toxoplasmose bei Schafen in Ägypten. Mh. Veter-Med., 27, 1972: 183-188

MUNDAY, B. L. - MASON, R. W.: Toxoplasmosis as a cause of perinatal death in goats. Austral. veter. J., 55, 1979: 485-487

NICOLAS, J. A. - PESTRE-ALEXANDRE, M. - MOUNIER, M. - CHAUCHEF, S. - RADEFF, J. - MONDOLY, P. - CUPRÉ, C. - PELINARD, P.: La toxoplasmose, cause d'avortements chez la brebis. Rev. Méd. vétér., 129, 1978: 407-414

NURSE, G. H. - LENGHAUS, C.: An outbreak of Toxoplasma gondii abortion, mummification and perinatal death in goats. Austral. veter. J., 63, 1986: 27-29

OWEN, D. - CHESUM, B. S.: Observations of dye test (DT) titres of Toxoplasma in a non-breeding flock of sheep. Veter. Rec., 101, 1977: 402-404

PLANT, J. W. - RICHARDSON, N. - MOYLE, G. G.: Toxoplasma infection and abortion in sheep associated with feeding of grain contaminated with cat faeces. Austral. veter. J., 50, 1974: 19-21

PLANT, J. W. - GLASTONBURY, J. R. W. - SAUNDERS, E. J.: Toxoplasmosis in goats. Austral. veter. J., 56, 1980: 254

PUNKE, G.: Untersuchungen zum Vorkommen der Toxoplasma-Infektion beim Schaf. Dis., Berlin, 1968

RIEMANN, H. P. - MEYER, M. E. - THEIS, J. H. - KELSO, G. - BEHYMER, D. E.: Toxoplasmosis in an infant fed unpasteurized goat milk. J. Pediat., 87, 1975: 573

RUPPANNER, R. - RIEMANN, H. P. - FARVER, T. B. - WEST, G. - BEHYMER, D. E. - WIJAYASINGHE, C.: Prevalence of Coxiella burnetii (Q fever) and Toxoplasma gondii among dairy goats in California. Amer. J. veter. Res., 39, 1978: 867-870

SCHURIAN, E.: Untersuchungen über die Möglichkeit laktogener und intrauteriner Übertragung von Toxoplasma gondii bei latent infizierten Mutterschafen. Dis., FU Berlin, 1969

SPENCE, J. B. - BEATTIE, C. P. - FAULKNER, J. - HENRY, L. - WATSON, W. A.: Toxoplasma gondii in the semen of rams. Veter. Rec., 102, 1978: 38-39

SURVEILLANCE ANTROPOZOONOZZ V ČESKÉ REPUBLICE. Ústav veterinární osvěty, Pardubice, 1980-1989

TEALE, A. J. - BLEWETT, D. A. - MILLER. J. K. - BUXTON, D.: Experimentally induced toxoplasmosis in young rams: the clinical syndrome and semen secretion of toxoplasma. Veter. Rec., 111, 1982: 53-55

WALDELAND, H.: Toxoplasmosis in sheep. The prevalence of Toxoplasma antibodies in lambs and mature sheep from different parts of Norway. Acta veter. scand., 17, 1976: 432-440

WALDELAND, H.: Toxoplasmosis in sheep. Long-term epidemiological studies in four breeding flocks. Acta veter. scand., 18, 1977: 227-236 